\title{
Interação Entre Enfermeiro e Família do Recém- Nascido em Terapia Intensiva: Humanização do Cuidado
}

\author{
Dias, Mariana Barbosa \\ Universidade Federal do Piauí — marianadias@hotmail.com
}

\begin{abstract}
Introdução: a assistência prestada em unidade de terapia intensiva neonatal (UTIN) é predominantemente guiada pela supervalorização da patologia e de procedimentos técnicos em detrimento dos aspectos subjetivos que envolvem o bebê e sua família. Além da competência técnica, o enfermeiro em UTIN deve possuir sensibilidade acurada para envolver o binômio recém-nascido/ família em um cuidado holístico, onde suas necessidades são consideradas no planejamento da assistência. Objetivo: Analisar a interação entre o Enfermeiro e a família do RN em tratamento intensivo sob a ótica da Teoria de Paterson e Zderard; discutir a opinião do Enfermeiro quanto à interação desse profissional com a família do $\mathrm{RN}$ em tratamento intensivo e descrever como o cuidado integrado entre Enfermeiro e família do RN pode contribuir para o tratamento intensivo. Metodologia: Pesquisa qualitativa, a coleta de dados foi realizada através de uma entrevista semi-estruturada. Participaram desse estudo sete enfermeiras atuantes na UTIN de uma Maternidade de referência.Para análise dos dados utilizou-se a análise de conteúdo de Minayo. Resultados: a análise temática das unidades de sentido possibilitou a emersão de três categorias: assistência de enfermagem ao recém- nascido em terapia intensiva; a interação entre enfermeiro e família do $\mathrm{RN}$ em terapia intensiva; cuidado integrado entre enfermeiro e família do RN em terapia intensiva. a maioria das enfermeiras verbalizou o interesse numa relação mais próxima, mais completa com os pais, entretanto, a rígida rotina de trabalho muitas vezes impossibilita essa interação.Conclusão: Conclui-se que a equipe de enfermagem demonstrou a importância de cuidar além da doença, respeitando a criança como ser humano. Desta forma, para que se alcance o cuidado dialógico proposto na Teoria Humanística de Paterson e Zderad a família deve ser vista além da ótica dos cuidados com o bebê e suas dificuldades de diferentes ordens devem ser assistenciadas para que assim a enfermagem possa significar o cuidado humanizado.
\end{abstract}

Palavras-chave: humanização da assistência; criança hospitalizada; Enfermagem Neonatal.

Dias, Mariana Barbosa. Interação Entre Enfermeiro e Família do Recém- Nascido em Terapia Intensiva: Humanização do Cuidado. In: Anais do Congresso Internacional de Humanidades \& Humanização em Saúde [= Blucher Medical Proceedings, num.2, vol.1]. São Paulo: Editora Blucher, 2014. ISSN 2357-7282

DOI 10.5151/medpro-cihhs-10806 